\title{
Upaya Peningkatan Keaktifan dan Prestasi Belajar Siswa dengan Menerapkan Model Pembelajaran Discovery pada Mata Pelajaran Biologi Materi Metabolisme Sel di SMAN 1 Palibelo Semester 1 Tahun Pelajaran 2020/2021
}

\author{
Abdurahman \\ SMA Negeri 1 Palibelo, Bima, Indonesia
}

\author{
*Coresponding Author : manabdurrahman82@gmail.com \\ Dikirim: 19-08-2021; Direvisi: 24-10-2021; Diterima: 25-10-2021
}

\begin{abstract}
Abstrak: Hasil refleksi pra-sklus menunjukan, rendahnya hasil belajar siswa dengan indikator rata-rata yakni yakni rata-rata 67, dengan ketuntasan klasikal 70\%. Demikian juga dengan kinerja guru APKG I 85.00 dan APKG II 80.00. Berdasarkan latar belakan masalah tersebut peneliti merumuskan masalah sebagai berikut: Bagaimanakah Upaya Peningkatan keaktifan dan Prestasi Belajar Siswa dengan Menerapkan Model Pembelajaran Discovery pada Mata Pelajaran Biologi Materi Metabolisme Sel di SMAN 1 Palibelo Semester 1 Tahun Pelajaran 2020/2021? Tujuan Penelitian Perbaikan Pembelajaran: 1) Mendeskripsikan penerapan pengunaan model pembelajaran discovery learning untuk meningkatkan keaktifan dan pprestasi belajar siswa pada pembelajaran Biologi materi metabolisme sel di SMAN 1 Palibelo semester I tahun pelajaran 2020/2021. 2) Mendeskripsikan cara meningkatkan keaktifan dan pprestasi belajar siswa Kelas XII IPA-1 SMAN 1 Palibelo pada pembelajaran Biologi materi metabolisme sel semester I tahun pelajaran 2020/2021 melalui model pembelajaran discovery learning. 3. Menganalisis dampak penerapan model pembelajaran discovery learning untuk meningkatkan keaktifan dan pprestasi belajar siswa pada pembelajaran Biologi materi metabolisme sel di kelas XII IPA-1 SMAN 1 Palibelo tahun pelajaran 2020/2021. Obyek dalam penelitian ini adalah siswa Kelas XII IPA-1 SMAN 1 Palibelo pada pembelajaran Biologi materi metabolisme sel semester I tahun pelajaran 2020/2021 melalui model pembelajaran discovery learning. Subyek dalam penelitian ini adalah jumlah siswa 31 siswa terdiri dari 15 laki-laki dan 16 perempuan. Perbaikan dilaksanakan dalam 2 (dua) siklus. Siklus I dari tanggal 25 Oktober 2020 sampai dengan 05 November 2020 dan siklus II dilaksanakan tanggal 10 November 2020 sampai dengan 23 November 2020. Hasil pos tes siklus I diatas menunjukkan bahwa prestasi belajar siswa ratarata $69,00(+2,00)$, tetapi nilai ini belum memenuhi indikator kinerja yang ditetapkan yakni rata-rata $\geq 70$. Persentase ketuntasan $72,00 \%$, Persentase ini masih dibawah indikator kinerja yakni $\geq 85 \%$. Dari sisi prestasi belajar siklus I (pertama) belum berhasil. Skor kinerja guru kompetensi guru dalam perencanaan pembelajaran APKG I pada siklus I 88.00\%. $(+3,00)$. Kinerja guru kompetensi guru dalam pelaksanaan pembelajaran APKG II pada siklus I $82.00 \%(+2,00)$. Dengan demikian dari sisi kinerja guru siklus I belum mencapai indikator kinerja yang ditetapkan yakni APKG I $\geq 93,00$ dan APKG II $\geq 91,00$. Pada pembelajaran hasil pos tes siklus II diatas menunjukkan bahwa prestasi belajar siswa rata-rata 75,50 $(+6,00)$. Persentase ketuntasan $87,00 \%(+15,00)$. Persentase ini telah memenuhi indikator kinerja yakni $\geq 85 \%$. Dengan demikian pada siklus II ini telah berhasil mencapai indikator yang ditetapkan yakni rata-rata $\geq 70$ dan persentase ketuntasan $\geq 85 \%$. Dari sisi prestasi belajar siklus II (kedua) telah berhasil. Kinerja guru menunjukkan bahwa skor ketuntasan guru dalam menyusun Rencana Pembelajaran APKG I dengan prosestase $95.00(+7,00)$. Ketuntasan guru dalam melaksanakan rencana pelaksanaan pembelajaran APKG II 93,00 $(+11,00)$. Dengan perbaikan proses pembelajaran berhasil memenuhi indikator kinerja yang ditetapkan yakni APKG I $\geq 93,00$ dan APKG II $\geq 91,00$. Peningkatkan prestasi belajar siswa, disebabkan oleh peningkatan aktivitas, interaksi guru dan siswa dalam proses pembelajaran
\end{abstract}


di kelas dengan pembelajaran discovery learning. Dengan demikian setelah pelaksanaan perbaikan pembelajaran sampai siklus II, telah mencapai indikator kinerja yang ditetapkan, dan penelitian dianggap telah berhasil.

Kata Kunci: Prestasi belajar; Biologi; pembelajaran discovery learning

Abstract: The results of pre-cycle reflections show that students' learning outcomes are low with an average indicator, namely an average of 67, with a classical completeness of $70 \%$. Likewise with the performance of APKG I 85.00 and APKG II 80.00 teachers. Based on the background of the problem, the researcher formulated the problem as follows: How are the Efforts to Increase Student Activity and Learning Achievement by Applying the Discovery Learning Model in Biology Subjects for Cell Metabolism at SMAN 1 Palibelo Semester 1 for the 2020/2021 Academic Year? Research Objectives for Learning Improvement: 1. Describe the application of the use of discovery learning models to increase student activity and achievement in learning biology material on cell metabolism at SMAN 1 Palibelo in the first semester of the 2020/2021 academic year. 2. Describe how to increase the activeness and learning achievement of Class XII IPA-1 students of SMAN 1 Palibelo in Biology learning material for cell metabolism in the first semester of the 2020/2021 academic year through the discovery model. 3. Analyzing the impact of the application of the discovery learning learning model to increase student activity and achievement in learning biology material for cell metabolism in class XII IPA-1 SMAN 1 Palibelo in the 2020/2021 school year. The objects in this study were students of Class XII IPA-1 SMAN 1 Palibelo in learning biology material for cell metabolism in the first semester of the 2020/2021 academic year through the discovery learning model. The subjects in this study were 31 students consisting of 15 boys and 16 girls. Repairs are carried out in 2 (two) cycles. Cycle I from October 25, 2020 to November 5, 2020 and cycle II is held from November 10, 2020 to November 23, 2020. The results of the post-test cycle I above show that student learning achievement is on average $69.00(+2.00)$, but this value does not meet the specified performance indicators, namely an average of 70 . The percentage of completeness is $72.00 \%$, this percentage is still below the performance indicator of $85 \%$. In terms of learning achievement, the first (first) cycle has not been successful. The teacher's performance score of teacher competence in APKG I learning planning in the first cycle is $88.00 \%$. $(+3.00)$. Teacher performance of teacher competence in the implementation of APKG II learning in the first cycle is $82.00 \%(+2.00)$. Thus, in terms of teacher performance in cycle I, the performance indicators have not yet reached the set performance indicators, namely APKG I 93.00 and APKG II 91.00. In the post-test learning cycle II above, it shows that the average student achievement is $75.50(+6.00)$. The percentage of completeness is $87.00 \%(+15.00)$. This percentage has met the performance indicators, namely $85 \%$. Thus, in the second cycle, it has succeeded in achieving the specified indicators, namely an average of 70 and a percentage of completeness of $85 \%$. In terms of learning achievement, cycle II (second) has been successful. The teacher's performance shows that the teacher's mastery score in preparing the APKG I Learning Plan with a process of $95.00(+7.00)$. The mastery of the teacher in implementing the APKG II learning implementation plan is $93.00(+11.00)$. By improving the learning process, the performance indicators have been met, namely APKG I 93.00 and APKG II 91.00. Improved student achievement, caused by increased activity, interaction of teachers and students in the learning process in the classroom with discovery learning. Thus, after the implementation of learning improvements up to cycle II, the performance indicators have been achieved, and the research is considered successful.

Keywords: learning achievement; Biology; discovery learning 


\section{PENDAHULUAN}

Dalam melaksanakan Kurikulum 2013, permasalahan pembelajaran menjadi salah satu perhatian utama dalam proses pendidikan khususnya di jenjang SMA. Guru sebagai fasilitator memegang peranan sentral dalam proses pembelajaran. Namun demikian saat ini meskipun kurikulum sudah berubah tetapi masih terdapat guru yang mengandalkan metode pembelajaran konvensional yakni dengan menggaunkan metode ceramah dan bertumpu pada sumber belajar buku teks tunggal yang cenderung sama di seluruh Indonesia tanpa ada upaya memperkaya dengan referensi aktual lainnya. Kebutuhan-kebutuhan siswa baik fisik maupun emosional jarang dipertimbangkan dalam proses pembelajaran, dan hasilnya pembelajaran menjadi monoton dan membosankan. Pendekatan saintifik yang telah direkomendasikan sesuai Kurikulum 2013, sebatas teoritis, di lapangan, dalam proses pembelajaran tetap kembali pada metode andalan: ceramah.

Kurikulum 2013 menyebutkan bahwa pada implementasi Kurikulum 2013 sangat disarankan menggunakan model-model pembelajaran inquiry based learning, discovery learning, project based learning dan problem based learning. Pada setiap model tersebut dapat dikembangkan sikap, pengetahuan, dan keterampilan.

Selain itu, saat ini merupakan tuntutan jaman bahwa guru dituntut mampu menciptakan pembelajaran yang kontekstual sesui Kurikulum 2013 yang berkaitan dengan kehidupan nyata siswa sehari-hari yang tentu dibutuhkan kreativitas guru. Berbagai upaya guru dilakukan untuk hal tersebut seperti dengan menggunakan media pembelajaran yang berfariasi, penerapan model pembelajaran yang relefan.

Peneliti pada pra-siklus dalam pelaksanaan pembelajaran melakukan pembelajaran seperti tahun-tahun sebelumnya tidak mempedulikan model pembelajaran yang sesuai dengan kurikulum. Hasil pembelajaran mengecewakan peneliti. Prestasi belajar siswa rendah dengan rata-rata 67, dengan ketuntasan klasikal 70\%. Demikian juga dengan kinerja guru APKG I 85.00 dan APKG II 80.00. Hal ini masih jauh dibawah indikator yang ditetapkan yakni Prestasi belajar siswa rendah dengan rata-rata minimal 70 , dengan ketuntasan klasikal minimal $85 \%$. Demikian juga dengan kinerja guru APKG I minimal 93.00 dan APKG II minimal 91.00.

Pada pra-siklus selama pembelajaran berlangsung, jarang siswa yang mengajukan pertanyaan atau memberikan tanggapan terhadap penjelasan guru. Berdasarkan hal tersebut, peneliti meminta bantuan teman sejawat untuk mengidentifikasi kekurangan dari pembelajaran yang dilaksanakan. Dari hasil diskusi dengan teman sejawat terungkap beberapa masalah yang terjadi dalam pembelajaran yaitu: a) Kemampuan guru dalam menggunakan model pembelajaran tidak sesuai dengan Kurikulum 2013; b) Sarana dan prasarana pembelajaran kurang memadai; c) Kemauan dari siswa atau memotivasi siswa untuk belajar masih kurang; d) Rendahnya kerjasama siswa dalam kelompok; 4) Rendahnya kemampuan siswa dalam menganalisis dan memecahkan dan menyimpulkan sebuah masalah; 5) Rendahnya prestasi belajar siswa; 6) Melalui diskusi dengan teman sejawat diketahui bahwa faktor penyebab rendahnya tingkat penguasaan siswa terhadap materi pelajaran adalah: a) Kemampuan guru dalam menggunakan model pembelajaran tidak sesuai dengan Kurikulum 2013; b) Rendahnya kerjasama siswa dalam kelompok; c) Rendahnya kemampuan siswa dalam menganalisis dan memecahkan dan menyimpulkan sebuah masalah; d) Rendahnya prestasi belajar siswa. 
Tidak tepatnya metode, model pembelajaran dan tidak adanya media pembelajaran menjadi pokok pemikiran dan kajian peneliti sebelum melakukan perbaikan pembelajaran. Kurikulum 2013 telah merekomendasikan model pembelajaran discovery learning.

Dengan kelebihannya, model pembelajaran yang tepat dengan kondisi siswa dan karakteristik materi pembelajaran tersebut adalah model pembelajaran discovery learning. Dengan model pembelajaran tersebut diharapkan dapat mengatasi permasalahan pada pembelajaran Biologi materi metabolisme sel di kelas XII IPA-1 semester I SMAN 1 Palibelo tahun pelajaran 2020/2021.

\section{KAJIAN TEORI}

\section{Keaktifan}

Dalam (Kamus Besar Bahasa Indonesia: 19) keaktifan adalah suatu kegiatan dan kesibukan. Keaktifan menurut Dimyati (1995: 115) adalah keterlibatas intelektual-emosional siswa secara optimal dalam pembelajaran.

Keatifan siswa dalam peristiwa pembelajaran mengambil beraneka bentuk kegiatan, dari kegiatan fisik yang mudah diamati sampai kegiatan psikisyang sulit diamati. Kegiatan fisik yang dapat diamati di antaranya dakam bentuk kegiatan membaca, mendengarkan, menulis, meragakan, dan mengukur. Sedangkan contohcontoh kegiatan psikis seperti mengingat kembali isi pelajaran pertemuan sebelumnya, menggunakan kekhasan pengetahuan yang dimiliki dalan memecahkan masalah yang dihadapi.

Keaktifan adalah kegiatan yang bersifat fisik maupun mental, yaitu berbuat dan berpikir sebagai suatu rangkaian yang tidak dapat dipisahkan (Sardiman 2001:98). Keaktifan yang dikemukakan oleh Mulyono (2001: 26) adalah kegiatan atau aktivitas atau segala sesuatu yang dilakukan atau kegiatan-kegiatan yang terjadi baik fisik maupun non fisik.

Dari pengertian menurut beberapa tokoh di atas dapat disimpulkan Keaktifan adalah kegiatan siswa yang melibatkan intelektual-emosional dalam pembelajaran.

Berdasarkan penjelasan indikator-indikator keaktifan di atas, maka dalam penelitian ini indikator keaktifan juga akan dimunculkan melalui kegiatan fisik dan kegiatan psikis. Indikator keaktifan yang digunakan untuk mengukur keaktifan diantaranya.

\section{Belajar dan prestasi belajar}

Belajar merupakan suatu proses perubahan tingkah laku sebagai hasil interaksi individu dengan lingkungannya dalam memenuhi kebutuhan hidupnya. Menurut Slameto (2010: 2) "belajar ialah suatu proses usaha yang dilakukan seseorang untuk memperoleh suatu perubahan tingkah laku yang baru secara keseluruhan, sebagai hasil pengalamannya sendiri dalam interaksi dengan lingkungannya".

Menurut Sugihartono (2007: 74) "belajar merupakan suatu proses memperoleh pengetahuan dan pengalaman dalam wujud perubahan tingkah laku dan kemampuan bereaksi yang relatif permanen atau menetap karena adanya interaksi individu dengan lingkungannya".

Menurut Ngalim (2006: 102) "belajar adalah suatu proses yang menimbulkan terjadinya suatu perubahan atau pembaharuan dalam tingkah laku dan atau 
kecakapan”. Wina (2009: 112) "belajar adalah proses mental yang terjadi di dalam diri seseorang, sehingga menyebabkan munculnya perubahan prilaku. Aktivitas mental itu terjadi karena adanya interaksi individu dengan lingkungan yang disadari".

Prestasi belajar menurut Winkel yang dikutip Noor Komari Pratiwi (2015:81) merupakan "bukti keberhasilan yang telah dicapai oleh seseorang. Dengan demikian, prestasi belajar merupakan hasil maksimum yang dicapai oleh seseorang setelah melakukan usaha-usaha belajar".

Menurut Siti Maesaroh (2013:11) menerangkan bahwa "prestasi belajar merupakan hasil daripada aktivitas belajar atau hasil dari usaha, latihan dan pengalaman yang dilakukan oleh seseorang, dimana prestasi tersebut tidak akan lepas dari pengaruh faktor luar diri peserta didik".

Untuk mengetahui seberapa jauh prestasi belajar telah dicapai peserta didik, maka diadakan kegiatan evaluasi pembelajaran. Tujuan diadakannya kegiatan evaluasi adalah untuk mengetahui keefektifan dan keberhasilan belajar mengajar sehingga dalam pelaksanaannya evaluasi harus dilakukan secara terus-menerus.

Zainal Arifin yang dikutip Risnawati (2018:7) prestasi belajar mempunyai beberapa fungsi sebagai berikut:

a) Indikator kualitas dan kuantitas pengetahuan yang telah dikuasai peserta didik.

b) Lambang pemuasan hasrat ingin tahu.

c) Bahan informasi dalam inovasi pendidikan.

d) Indikator intern dan ekstern dari suatu institusi pendidikan.

e) Dapat dijadikan sebagai indikator terhadap daya serap anak didik.

Indikator Prestasi Belajar

Prestasi belajar merupakan hasil dari proses belajar yang berupa pengetahuan dan keterampilan yang dapat diukur dengan tes. Tes yang dilakukan dalam mengukur prestasi belajar harus sesuai dengan indikator prestasi belajar.

\section{Pengukuran Prestasi Belajar}

Menurut Sugihartono (2007: 130) menyatakan: Dalam kegiatan belajar mengajar, pengukuran hasil belajar dimaksudkan untuk mengetahui seberapa jauh perubahan tingkah laku siswa setelah menghayati proses belajar. Maka pengukuran yang dilakukan guru lazimnya menggunakan tes sebagai alat ukur. Hasil pengukuran tersebut berwujud angka ataupun pernyataan yang mencerminkan tingkat penguasaan materi pelajaran bagi para siswa, yang lebih dikenal dengan prestasi belajar.

Ada tiga ranah yang harus dilihat dalam tingkat keberhasilan yang dapat dicapai siswa yaitu : Ranah kogntif; Ranah afektif; dan Ranah psikomotorik

\section{Siswa SMA Sebagai Remaja Pertengahan}

Dalam bukunya Psikologi Perkembangan (2011: 26), Hurlock menjelaskan bahwa istilah remaja atau adolescence berasal dari kata lain adolescere yang berarti "tumbuh" atau "tumbuh menjadi dewasa".

\section{Ciri-ciri Siswa SMA Sebagai Remaja Pertengahan (Hurlock, 2011: 38-49)}

a) Masa remaja sebagai periode peralihan

Pada masa ini, apa yang telah terjadi sebelumnya akan meninggalkan bekas pada apa yang terjadi sekarang dan yang akan datang. Menurut Hurlock (2011: 38), menjelaskan bahwa struktur psikis anak remaja berasal dari masa kanak-kanak. 
b) Masa remaja sebagai periode perubahan

(Hurlock, 2011: 44). Pada periode ini, dimungkinkan siswa SMA mengalami kecemasan. Hal ini dilatarbelakangi oleh timbulnya masalah baru, di mana masalah yang timbul ini lebih banyak dan lebih sulit diselesaikan dibandingkan masalah yang sebelumnya pernah alami.

c) Masa remaja sebagai usia bermasalah

Masa remaja sering terjadi masalah yang sulit diatasi baik oleh anak laki-laki maupun anak perempuan. Ada dua alasan adanya kesulitan tersebut. Pertama, kebanyakan remaja tidak berpengalaman dalam mengatasi masalah mereka sebagian diselesaikan oleh orang tua dan guru-guru sepanjang masa kanak-kanak. Kedua, karena para remaja merasa diri mereka mandiri, sehingga mereka ingin mengatasi masalahnya sendiri dan menolak bantuan orang tua dan guru-guru (Hurlock, 2011).

d.) Masa remaja sebagai usia yang menimbulkan ketakutan

Menurut Hurlock (1991: 50), mengungkapkan bahwa banyak anggapan populer tentang remaja yang sebagian besar bersifat negatif. Stereotip budaya mengganggap bahwa remaja merupakan anak-anakyang tidak rapi, tidak dapat dipercaya, cenderung merusak, dan berperilaku merusak.

\section{Karakteristik Perkembangan Siswa SMA Sebagai Remaja Pertengahan}

Siswa SMA sebagai remaja Pertengahan memiliki beberapa karakteristik perkembangan (Santrock, 2003: 31-39). Karakteristik-karakteristik tersebut, antara lain:

1. Secara intelektual remaja mulai dapat berfikir logis tentang gagasan abstrak.

2. Berfungsinya kegiatan kognitif tingkat tinggi yaitu membuat rencana, strategi, membuat keputusan-keputusan, serta memecahkan masalah.

3. Sudah mampu menggunakan abstraksi-abstraksi, membedakan yang konkrit dengan yang abstrak.

4. Munculnya kemampuan nalar secara ilmiah, belajar menguji hipotesis.

5. Memikirkan masa depan, perencanaan, dan mengeksplorasi alternatif untuk mencapainya psikologi remaja. Mulai menyadari proses berfikir efisien dan belajar berinstropeksi

\section{Implementasi Kurikulum 2013 pembelajaran Biologi}

Implementasi menurut Mulyasa (2008) merupakan suatu proses penerapan ide, konsep, kebijakan, atau inovasi dalam suatu tindakan praktis sehingga memberikan dampak, baik berupa perubahan pengetahuan, keterampilan, nilai, dan sikap. Implementasi kurikulum 2013 pada penelitian ini adalah penerapan kurikulum 2013 pada aspek standar proses pembelajaran Biologi di kurikulum 2013.

Di dalam pembelajaran, peserta didik difasilitasi untuk terlibat secara aktif mengembangkan potensi dirinya menjadi kompetensi. Guru menyediakan pengalaman belajar bagi peserta didik untuk melakukan berbagai kegiatan yang memungkinkan mereka mengembangkan potensi yang dimiliki. Dengan demikian siswa memiliki keleluasaan mengembangkan potensi yang ada di dalam dirinya untuk mempersiapkan diri menghadapi tantangan di masa depan baik di masyarakat, lingkungan pekerjaan maupun dunia pendidikan yang lebih tinggi (Permendikbud No. 81 A Tahun 2013).

\section{Metode Discovery Learning}


Discovery Learning merupakan suatu model pembelajaran. Hal ini berangkat dari pernyataan bahwa Rancangan Pembelajaran disebutkan bahwa pada implementasi Kurikulum 2013 sangat disarankan menggunakan model-model pembelajaran inquiry based learning, discovery learning, project based learning dan problem based learning. Pada setiap model tersebut dapat dikembangkan sikap, pengetahuan, dan keterampilan (Kemdikbud, 2014).

Model pembelajaran discovery learning Menurut Alma dkk (2010:59). yang juga disebut sebagai pendekatan inkuiri bertitik tolak pada suatu keyakinan dalam rangka perkembangan murid secara independen. Model ini membutuhkan partisipasi aktif dalam penyelidikan secara ilmiah. Hal ini sejalan juga dengan pendapat yang menyatakan bahwa anak harus berperan aktif dalam belajar di kelas seperti yang terdapat pada kutipan: Discovery Learning dapat didefinisikan sebagai pembelajaran yang terjadi ketika siswa tidak disajikan dengan materi pelajaran dalam bentuk akhir, melainkan diminta untuk mengaturnya sendiri " (Lefancois dalam Emetembun, 1986: 103 dalam Depdikbud 2014).

\section{Sintaks, langkah-langkah Discovery Learning}

Yoki Ariyana mengumukakan model pembelajaran penyingkapan/penemuan (Discovery/inquiry Learning) adalah memahami konsep, arti, dan hubungan melalui proses intuitif untuk akhirnya sampai kepada suatu kesimpulan. Discovery terjadi bila individu terlibat terutama dalam penggunaan proses mentalnya untuk menemukan beberapa konsep dan prinsip. Discovery dilakukan melalui observasi, klasifikasi, pengukuran, prediksi, penentuan dan inferensi. Proses tersebut disebut cognitive process sedangkan discovery itu sendiri adalah the mental process of assimilating concepts and principles in the mind.

Langkah kerja (sintak) model pembelajaran penyingkapan/ penemuan adalah sebagai berikut:

1) Pemberian rangsangan (Stimulation);

2) Pernyataan/Identifikasi masalah (Problem Statement);

3) Pengumpulan data (Data Collection);

4) Pengolahan data (Data Processing);

5) Pembuktian (Verification), dan

6) Menarik simpulan/generalisasi (Generalization) (Yoki Ariyana, 2018).

\section{METODE PENELITIAN}

\section{Subyek Penelitian}

Subyek perbaikan adalah siswa-siswi kelas XII IPA-1 SMAN 1 Palibelo dengan jumlah siswa 31 siswa terdiri dari 15 laki-laki dan 16 perempuan. Adapun karakteristik siswa rata-rata memiliki intake, kemampuan akademik yang sedang. Kreativitas dan motivasi belajar siswa rata-rata rendah.

Faktor Yang diteliti. Adapun faktor-faktor yang akan diteliti adalah:

a. Prestasi belajar siswa, sejauh mana prestasi belajar pada pembelajaran Biologi materi metabolisme sel di kelas XII IPA-1 semester I SMAN 1 Palibelo tahun pelajaran 2020/2021. 
b. Kinerja guru, diteliti sejauh mana ketuntasan guru dalam perencanaan dan pelaksanaan pembelajaran sesuai dengan instrument yang telah ditetapkan yakni menggunakan APKG I dan APKG II.

\section{Tempat Penelitian}

Penelitian Perbaikan Pembelajaran ini dilakukan di Kelas XII IPA-1 SMAN 1 Palibelo Kabupaten Bima.

\section{Waktu Penelitian}

Perbaikan dilaksanakan dalam 2 (dua) siklus. Siklus I dari tanggal 25 Oktober 2020 sampai dengan 05 November 2020 dan siklus II dilaksanakan tanggal 10 November 2020 sampai dengan 23 November 2020.

\section{Pihak yang Membantu}

Adapun pihak-pihak yang membantu dalam penelitian ini adalah:

a. Kepala SMAN 1 Palibelo

b. Supervisor 2, guru senior di SMAN 1 Palibelo

c. Guru teman sejawat, sebagai observer dalam pelaksanaan penelitian

d. Siswa SMAN 1 Palibelo

\section{Desain Prosedur Perbaikan Pembelajaran}

\section{Data dan Cara Pengambilannya}

1) Sumber data : sumber data perbaikan ini adalah seluruh siswa kelas XII IPA-1 SMAN 1 Palibelo.

2) Jenis data :

a) Data kualitatif terdiri dari:

(1) Teacher's note (Rancangan Pembelajaran)

(2) Data hasil observasi pelaksanaan pembelajaran dan activitas siswa.

(3) Jurnal tim peneliti

b) Data Kuantitatif

(1) Nilai pos tes

(2) Nilai kinerja guru

3) Teknik Pengambilan data

(a) Data kualitatif diambil dari teacher's note (rencana pembelajaran) yang dibuat peneliti.

(b) Data tentang refleksi diri diambil dari jurnal yang dibuat oleh peneliti.

(c) Data kuantitatif diambil dari skor nilai tes siswa.

\section{Indikator Kinerja}

1. Prestasi belajar siswa, rata-rata nilai post test untuk pada pembelajaran Biologi $\geq 70$.

2. Prosentase ketuntasan belajar siswa $\geq 85 \%$

3. Kinerja Guru, ketuntasan guru dalam menyelesaikan Rencana Pelaksanaan Pembelajaran dalam APKG I $\geq 93.00$.

4. Kinerja Guru, ketuntasan guru dalam Pelaksanaan Pembelajaran dalam APKG II $\geq 91.00$.

5. Intrumen Perbaikan

a) Instrumen perbaikan berupa performance test.

b) Lembar observasi kinerja guru. 


\section{Deskripsi Per-siklus/Desain Perbaikan}

a. Siklus Perbaikan

Siklus perbaikan dilaksanakan dalam dua siklus. siklus. Tiap siklus terdiri dari 4 (empat) tahapan utama yakni: perencanaan; penerapan tindakan; observasi dan refleksi. Hasil refleksi akan menentukan apakah PTK dalam siklus tersebut berhasil atau belum berhasil. Jika belum berhasil maka akan dilanjutkan pada siklus berikutnya.

b. Rincian Prosedur Perbaikan

1) Siklus Pertama

a) Perencanaan adalah:

Dalam tahap perencanaan ini kegiatan pokok yang dilakukan

(1) Menyusun jadwal perbaikan

(2) Menyiapkan instrument pengamatan perbaikan

(3) Menyusun Rencana Pembelajaran (RPP)

(4) Mempersiapkan materi pembelajaran

b) Penerapan Tindakan

Melaksanakan Pembelajaran dengan mengacu pada penataan Skenario Pembelajaran.

c) Observasi

Dalam observasi ini peneliti mengobservasi seluruh rangkaian kegiatan proses pembelajaran apakah dapat berjalan seperti yang direncanakan atau tidak. Di sini peneliti dan observer melakukan pencatatan item-item kegiatan yang secara signifikan mempengaruhi proses pembelajaran, baik yang berpengaruh positif maupun negative. Obyek observasi meliputi aktivitas guru, siswa, serta efektivitas media yang digunakan. Observer juga menggunakan lembar observasi dengan mengisi item-item butir observasi yang telah dipersiapkan.

Dalam observasi ini akan menentukan ketercapaian indikatorindikator utama yang menjadi tolok ukur keberhasilan perbaikan ini khususnya kemapuan membaca dan menulis siswa dan kemampuan guru dalam melaksanakan dan menyelesaikan Rencana Pembelajaran (RPP) dengan langkah pembelajaran IPA yang mengacu pada model pembelajaran discovery learning.

d) Refleksi

Dengan menganalisa hasil observasi maka dilakukan refleksi, merenungkan kembali apa yang telah peneliti lakukan. Kegiatan refleksi ini bertujuan untuk:

1. Mengetahui dan menyimpulkan langkah-langkah manakah yang dapat berjalan seperti yang direncanakan.

2. Mengetahui dan menyimpulkan langkah-langkah manakah yang tidak dapat berjalan seperti yang direncanakan.

3. Mengetahui dan menimpulkan indikator manakah yang sudah tercapai dan indikator mana yang belum tercapai.

4. Yang paling penting adalah menentukan perbaikan pembelajaran pada siklus selanjutnya (siklus kedua). Perbaikan ini dapat mencakup aspek-aspek: 


\section{Siklus Kedua}
a. Pengelolaan kelas
b. Penataan skenario pembelajaran
c. Desain tes
d. Desain media pembelajaran
e. Dan temuan-temuan lainnya.

Kegiatan pada siklus kedua merupakan rangkaian kegiatan yang tidak terpisahkan dengan kegiatan siklus pertama. Langkah-langkah kegiatan siklus kedua tidak jauh berbeda dengan siklus pertama. Disini langkah-langkah direncanakan dan dilaksanakan berdasarkan hsil refleksi Penerapan tindakan siklus pertama.

Langkah-langkah utama tersebut adalah:
a. Perencanaan
b. Penerapan tindakan
c. Observasi dan
d. Refleksi

\section{Teknik Analisis Data}

\section{Teknik Pengumpulan Data}

Teknik pengumpulan data yang digunakan dalam penelitian ini terdiri dari 2 teknik, yaitu teknik observasi dan teknik tes.

1) Teknik Observasi

Observasi dilakukan selama kegiatan pembelajaran berlangsung dengan menggunakan lembar observasi yang dibuat untuk digunakan sebagai perangkat pengumpul data. Adapun hal-hal yang diobservasi antara lain:

a) Observasi terhadap rencana pembelajaran.

b) Observasi terhadap proses pembelajaran.

c) Observasi terhadap hasil yang diperoleh siswa setelah dilakukan tindakan.

2) Teknik Penilaian portofolio menggunakan non tes dengan rubrik penilaian

Teknik non tes dilakukan pada seluruh proses pembelajaran dengan menggungkan rubrik penilaian yang disiapkan.

3) Alat Pengumpulan Data

Alat pengumpulan data yang digunakan dalam penelitian ini adalah:

(1) Rubrik penilaian

(2) Lembar Observasi, yaitu:

a) Observasi terhadap rencana pembelajaran.

b) Observasi terhadap proses pembelajaran.

(3) Observasi terhadap hasil yang diperoleh siswa setelah dilakukan tindakan.

\section{Teknik Analisis Data}

Penelitian ini dikatakan berhasil jika ada perubahan-perubahan menuju arah kebaikan yang berkaitan dengan siswa, guru, suasana proses belajar di kelas dan perangkat pembelajaran. Perubahan yang terjadi dapat diketahui dengan membandingkan hasil sebelum dan sesudah diberi tindakan yang berkaitan dengan prestasi belajar siswa.

Penghitungan Prestasi Belajar siswa 
Analisis data prestasi belajar menggunakan non tes dengan rubric penilaian sebagai berikut:

- Menghitung nilai setiap siswa :

$$
\frac{\text { Jml.skor yang diperoleh dr deskriptor }}{\text { skor maksimal }} \times 100
$$

- Menghitung nilai rata-rata kelas menggunakan rumus :

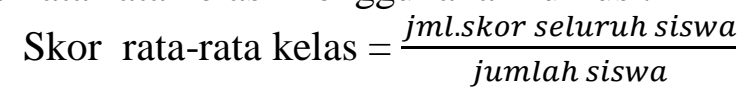

- Menghitung persentase jumlah siswa yang mencapai KKM dengan menggunakan rumus :

Persentase jumlah siswa yang mencapai $\mathrm{KKM}=$

$$
\frac{\text { jml.yang mencapai } K K M}{\text { jml.seluruh siswa }} \times 100 \%
$$

\section{HASIL DAN PEMBAHASAN}

\section{Deskripsi Hasil Penelitian Perbaikan Pembelajaran}

\section{Hasil Perbaikan}

\section{a. Perencanaan}

Model pembelajaran discovery learning dapat optimal diterapkan pada pembelajaran pembelajaran Biologi, maka peneliti melakukan revisi terhadap RPP yang telah disusun sebelumnya dengan cermat memperhatikan sintaks, langkahlangkah menerapkan model pembelajaran discovery learning yakni:

1) Pemberian rangsangan (Stimulation);

2) Pernyataan/Identifikasi masalah (Problem Statement);

3) Pengumpulan data (Data Collection);

4) Pengolahan data (Data Processing);

5) Pembuktian (Verification), dan

6) Menarik simpulan/generalisasi (Generalization).

Sintaks tersebut dijadikan acuan dalam menyusun RPP dengan menyesuaikan materi dan karakteristik siswa. Langkah-langkah sesuai sintaks disusun secara sistematik dan applicable, dapat diterapkan

\section{b. Pelaksanaan}

Pelaksanaan pembelajaran sudah barang tentu mengacu pada RPP yang telah disusun. Kegiatan pendahuluan dapat terlaksana dengan baik sesuai RPP.

Pada kegiatan inti lebih rinci per-langkah dibahas sebabagai berikut: Pendahuluan, dapat berjalan dengan baik. Kegiatan inti:

\section{Lankah Kerja 1: Pemberian rangsangan (Stimulation)}

- Guru memulai menayakan secara lisan kepada siswa:

- Apakah yang anak-anak ketahui tentang Kehidupan politik, ekonomi, sosial, dan budaya bangsa Indonesia pada masa awal ?

- Sebutkan jenis-jenis Kehidupan politik, ekonomi, sosial, dan budaya bangsa Indonesia pada masa awal, dan berikan contoh

- Apakah anak-anak dan orang tuamu melakukan kegiatan ekonomi?

- Untuk menjawab pertanyaan anak-anak bisa membaca buku atau sumber 
belajar lainnya. Siswa menjawab secara lisan

- Beberapa siswa dapat menjawab pertanyaan secara lisan, tetapi jawabannya belum tepat.

- Setelah diberi waktu untuk membaca referensi, sebagian besar siswa dapat menjawab dengan tepat, tetapi terdapat beberapa siswa yang tidak bisa menjawab pertanyaan dengan tepat.

\section{Langkah Kerja 2: Pernyataan/Identifikasi masalah (Problem Statement)}

- Guru Bentuklah kelompok, dengan anggota 5 siswa permkelompok.

- Dalam kelompok buatlah 1 pertanyaan yang berkaitan dengan kegiatan ekonomi kaitannya dengan kesejahteraan masyarakat.

- Kemudian tiap kelompok mengemukakan pertanyaan yang dibuat.

- 5 Kelompok bermusyawarah untuk menetapkan 1 pertanyaan yang akan dirumuskan menjadi masalah atau menjadi hipotesis.

- Kegiatan berjalan lancar dan dinamis, 4 kelompok dapat menyusun pertanyaan, satu kelompok masih bingung. Secara umum siswa memahami dan senang dengan kegiatan ini.

- Setelah berdiskusi 5 Kelompok bersepakat merumuskan permasalahan dalam kalimat tanya, yakni:

- Apakah ada Kehidupan politik, ekonomi, sosial, dan budaya bangsa Indonesia pada masa awal ?

\section{Langkah Kerja 3: Pengumpula n data (Data Collection)}

- Ketika eksplorasi berlangsung guru juga memberi kesempatan kepada para siswa untuk mengumpulkan informasi yang relevan sebanyak-banyaknya untuk membuktikan benar atau tidaknya hipotesis.

- Siswa dalam kelompok diberi kesempatan ke perpustakaan sekolah untuk mendapatkan informasi berkaitan dengan jawaban atas permasalahan/hipotesis yang dirumuskan. Siswa dalam kelompok disuruh merangkum dalam bentuk peta konsep.

- Kegiatan dapat berjalan dengan baik, tiap kelompok berkonsentrasi mendapatkan data dan informasi berkaitan dengan rumusan masalah/hipotesis: Apakah ada Kehidupan politik, ekonomi, sosial, dan budaya bangsa Indonesia pada masa awal ?

- 3 kelompok dapat menyusun peta konsep materi tersebut dengant tepat, dua kelompok dalam bentuk ringkasan materi.

- Dalam kegiatan ini 1 kelompok materinya belum lengkap dan beberapa materi tidak terkait dengan rumusan masalah.

- Aktivitas siswa dinamis, terdapat beberapa siswa yang tidak aktif erpartisipasi dalam kerja kelompok.

\section{Langkah kerja 4: Pengolahan data (Data Processing)}

- Guru melakukan bimbingan pada saat siswa melakukan pengolahan data.

- Guru membimbing siswa dalam pengolahan data mengolah data dan informasi baik melalui wawancara, observasi, dan sebagainya, lalu ditafsirkan. Semua informasi hasil bacaan, wawancara, observasi, dan sebagainya, semuanya diolah, diacak, diklasifikasikan, ditabulasi, bahkan bila perlu dihitung dengan cara tertentu serta ditafsirkan pada tingkat kepercayaan tertentu.

- Pada kegiatan ini, karena data sebagian besar bersifat kualitatif, maka tidak ada 
hitungan yang sifatnya kuantitatif rumit.

- Untuk membimbing dan menyederhanakan tabulasi data, disepakati bahwa: Informasi ditabelkan dalam tabel sederhana yakni, jenis kegiatan ekonomi, ada/tidak ada pengaruh terhadap kesejahteraan masyarakat.

- Pada tahapan ini terdapat kelompok yang masih bingung cara mengisi tabel, karena anggota kelompok sebagian tidak aktif.

\section{Lankgah Kerja 5: Pembuktian (Verification)}

- Guru menyuruh siswa kembali membaca, mencermati hipotesis/pertanyaan yang menjadi pokok masalah.

- Siswa disuruh memeriksa, mempelajari informasi, data yang telah diolah dikaitkan dengan hipotesis/pertanyaan yang menjadi pokok masalah.

- Pada kegiatan ini sebagian besar siswa tidak tahu cara memaknai data dalam tabel tersebut, sehingga diskusi berjalan lebih lama dari waktu yang ditentukan.

\section{Langkah Kerja 6: Menarik simpulan/ge neralisasi (Generalizati on)}

- Siswa disuruh menyimpulakan benar tidaknya, hipotesis/pertanyaan yang menjadi pokok masalah, dengan menjelaskan secara tertulis dalam laporan sederhana berdasarkan informasi, data yang telah diperloeh dan diolah.

- Pada penyimpulan ini, sebagian besar siswa belum tahu caranya. Guru memberikan penjelasan berdasarkan tabulasi data. Dengan sederhana dihitung ada berapa kegiatan ekonomi yang berhasil diidentifikasi, ada berapa yang berpengaruh pada kesejahteraan masyarakat, ada berapa yang tidak berpengaruh. Dengan bimbingan tersebut seluruh kelompok dapat mengambil kesimpulan ada tidaknya Kehidupan politik, ekonomi, sosial, dan budaya bangsa Indonesia pada masa awal .

- Beberapa kelompok kesulitan menyusun laporan berdasarkan data yang diperoleh.

- Pada kegiatan ini masih terdapat siswa yang kurang aktif.

\section{Kegiatan penutup:}

- Kegiatan penutup dapat dilaksanakan dengan baik.

- Meskipun belum optimal, pembelajaran siklus I berhasil dilaksanakan.

- Adapun prestasi belajar (pos tes) dan kinerja guru Siklus I dilanjutkan data prestasi belajar (pos tes) dan kinerja guru Siklus II sebagai berikut:

Tabel 1. Nilai Prestasi Belajar Siswa dan Kinerja Guru Siklus I dan Siklus II

\begin{tabular}{|l|c|c|}
\hline \multicolumn{1}{|c|}{ Siklus } & Nilai Rata-Rata & Porsentase Ketuntasan \\
\hline Pra Siklus & 67,00 & 70,00 \\
\hline Siklus I & 69,00 & 72,00 \\
\hline Siklus II & 75,50 & 87,00 \\
\hline
\end{tabular}

Tabel 2. Kinerja Guru

\begin{tabular}{|l|c|c|}
\hline \multicolumn{1}{|c|}{ Siklus } & APKG I & APKG II \\
\hline Pra Siklus & 85.00 & 80.00 \\
\hline Siklus I & 88.00 & 82.00 \\
\hline Siklus II & 95.00 & 93.00 \\
\hline
\end{tabular}

\section{c. Observasi}

Kegiatan observasi dilakukan oleh observer mengamati jalannya proses pembelajaran. Dalam observasi ini observer menggunakan lembar observasi dimana 
dalam format lembar observasi mengacu pada instrumen penilaian kinerja guru APKG I untuk perencanaan pembelajaran dan APKG II untuk pelaksanaan pembelajaran. Kompetensi guru dalam perencanaan dan melaksanakan perencanaan dan pelaksanaan pembelajaran diberikan skor dengan rentangan 1-5 dan hasil akhir dihitung dengan skor maksimal 5.

\section{Pembahasan Siklus I}

\section{Prestasi Belajar}

Hasil pos tes siklus I diatas menunjukkan bahwa prestasi belajar siswa rata-rata 69,00. Meskipun nilai rata-rata ini telah mengalami peningkatan dibanding sebelum diadakan perbaikan $(+2,00)$, tetapi nilai ini belum memenuhi indikator kinerja yang ditetapkan yakni rata-rata $\geq 70$. Persentase ketuntasan $72,00 \%$, Persentase ini masih dibawah indikator kinerja yakni $\geq 85 \%$. Dari sisi prestasi belajar siklus I (pertama) belum berhasil.

\section{Kinerja Guru}

Skor kinerja guru kompetensi guru dalam perencanaan pembelajaran APKG I pada siklus I $88.00 \%$. Mengalami peningkatan dibanding prasiklus $(+3,00)$. Kinerja guru kompetensi guru dalam pelaksanaan pembelajaran APKG II pada siklus I $82.00 \%$. Mengalami peningkatan $(+2,00)$. Dengan demikian dari sisi kinerja guru siklus I belum mencapai indikator kinerja yang ditetapkan yakni APKG I $\geq 93,00$ dan APKG II $\geq 91,00$.

\section{Refleksi}

Rencana Pembelajaran (RPP) sudah cukup bagus, secara substansial sudah sesuai dengan model pembelajaran dan materi yang ada. Bagian yang masih perlu direfisi agar kerja kelompok lebih efektif.

Rencana Pembelajaran (RPP) sudah cukup bagus, secara substansial sudah sesuai dengan model pembelajaran discovery learning yakni:

1) Pemberian rangsangan (Stimulation);

2) Pernyataan/Identifikasi masalah (Problem Statement);

3) Pengumpulan data (Data Collection);

4) Pengolahan data (Data Processing);

5) Pembuktian (Verification), dan

6) Menarik simpulan/generalisasi (Generalization). dan materi yang ada. Terdapat bagian yang masih perlu direfisi agar kerja kelompok lebih efektif.

Belum tercapainya indikator prestasai belajar siswa disebabkan belum tercapainya indikator kinerja guru pada pelaksanaan pembelajara. Guru belum mampu melaksanakan seluruh langkah-langkah yang ditetapkan dalam RPP khusunya pada kegiatan inti. Secara rinci perbaikan pelaksanaan pembelajaran tersebut adalah:

Pendahuluan, dapat berjalan dengan baik.

Kegiatan inti:

\section{Lankah Kerja 1: Pemberian rangsangan (Stimulation)}

- Beberapa siswa dapat menjawab pertanyaan secara lisan, tetapi jawabannya belum tepat.

- Setelah diberi waktu untuk membaca referensi, sebagian besar siswa dapat 
menjawab dengan tepat, tetapi terdapat beberapa siswa yang tidak bisa menjawab pertanyaan dengan tepat. Guru dapat mengoptimalkan kegiatan ini dengan menyederhanakan perintah, petunjuk.

\section{Langkah Kerja 2: Pernyataan/Identifikasi masalah (Problem Statement)}

- Kegiatan berjalan lancar dan dinamis, 4 kelompok dapat menyusun pertanyaan, satu kelompok masih bingung. Secara umum siswa memahami dan senang dengan kegiatan ini.

- Setelah berdiskusi 5 Kelompok bersepakat merumuskan permasalahan dalam kalimat tanya, yakni: Apakah ada Kehidupan politik, ekonomi, sosial, dan budaya bangsa Indonesia pada masa awal ?

- Berarti pada langkah kedua sudah bagus.

Langkah Kerja 3: Pengumpulan data (Data Collection)

- Kegiatan dapat berjalan dengan baik, tiap kelompok berkonsentrasi mendapatkan data dan informasi berkaitan dengan rumusan masalah/hipotesis: Apakah ada Kehidupan politik, ekonomi, sosial, dan budaya bangsa Indonesia pada masa awal ?

- 3 kelompok dapat menyusun peta konsep materi tersebut dengant tepat, dua kelompok dalam bentuk ringkasan materi.

- Dalam kegiatan ini 1 kelompok materinya belum lengkap dan beberapa materi tidak terkait dengan rumusan masalah.

- Aktivitas siswa dinamis, terdapat beberapa siswa yang tidak aktif berpartisipasi dalam kerja kelompok.

- Guru perlu memberikan perhatian, bimbingan dan motivasi khusus kepada siswa yang tidak aktif untuk dapat berpartisipasi dalam pembelajaran.

\section{Langkah kerja 4: Pengolahan data (Data Processing)}

- Pada kegiatan ini, karena data sebagian besar bersifat kualitatif, maka tidak ada hitungan yang sifatnya kuantitatif rumit.

- Untuk membimbing dan menyederhanakan tabulasi data, disepakati bahwa: Informasi ditabelkan dalam tabel sederhana yakni, jenis kegiatan ekonomi, ada/tidak ada pengaruh terhadap kesejahteraan masyarakat.

- Pada tahapan ini terdapat kelompok yang masih bingung cara mengisi tabel, karena anggota kelompok sebagian tidak aktif.

- Guru perlu membimbing khusus pada kelompok dan siswa yang masih bingung. Guru juga dapat menjadikan siswa lain sebagai tutor sebaya dalam mengatasi permasalahan ini.

\section{Lankgah Kerja 5: Pembuktian (Verification)}

Pada kegiatan ini sebagian besar siswa tidak tahu cara memaknai data dalam tabel tersebut, sehingga diskusi berjalan lebih lama dari waktu yang ditentukan. Guru perlu menyederhanakan penjelasan dan memberikan contoh sebagai model siswa untukenyelesaikan langkah ke-5.

\section{Langkah Kerja 6: Menarik simpulan/ge neralisasi (Generalizati on)}

- Siswa disuruh menyimpulakan benar tidaknya, hipotesis/pertanyaan yang menjadi pokok masalah, dengan menjelaskan secara tertulis dalam laporan sederhana berdasarkan informasi, data yang telah diperloeh dan diolah.

- Pada penyimpulan ini, sebagian besar siswa belum tahu caranya. Guru memberikan penjelasan berdasarkan tabulasi data. Dengan sederhana dihitung ada berapa kegiatan ekonomi yang berhasil diidentifikasi, ada berapa yang 
berpengaruh pada kesejahteraan masyarakat, ada berapa yang tidak berpengaruh. Dengan bimbingan tersebut seluruh kelompok dapat mengambil kesimpulan ada tidaknya Kehidupan politik, ekonomi, sosial, dan budaya bangsa Indonesia pada masa awal .

- Beberapa kelompok kesulitan menyusun laporan berdasarkan data yang diperoleh.

- Pada kegiatan ini masih terdapat siswa yang kurang aktif.

- Guru perlu memberikan sistematika sederhana disertai conoth secukupnya, dengan demikian siswa dapat mencontoh dari model yang ada disesuaikan dengan data siswa. Guru perlu membimbing khusus siswa yang tidak aktif dengan berbagai teknik memberikan motivasi.

- Kegiatan penutup:

- Kegiatan penutup dapat dilaksanakan dengan baik.

\section{Pembahasan Siklus II}

\section{Hasil perbaikan}

\section{1) Perencanaan}

Perencanaan siklus II dilakukan perbaikan pada langkah-langkah dalam kegiatan inti menyesuaikan dengan pendekatan dan penilain yang digunakan dengan mempertimbangkan hasil refleksi siklus I.

\section{2) Penerapan Tindakan}

Pembelajaran dilakukan perubahan pada langkah-langkah sesuai hasil refleksi siklus I. Adapun langkah-langkah kegiatan inti yang telah diperbaiki dalam pelaksanaan pembelajaran adalah:

\section{Lankah Kerja 1: Pemberian rangsangan (Stimulation)} petunjuk.

Guru dapat mengoptimalkan kegiatan ini dengan menyederhanakan perintah,

Langkah Kerja 2: Pernyataan/ Identifikasi masalah (Problem Statement), sudah bagus.

Langkah Kerja 3: Pengumpula n data (Data Collection)

Guru berhasil memperbaiki pembelajaran dengan memberikan perhatian, bimbingan dan motivasi khusus kepada siswa yang tidak aktif untuk dapat berpartisipasi dalam pembelajaran.

\section{Langkah kerja 4:Pengolahan data (Data Processing)}

Guru telah mampu membimbing khusus pada kelompok dan siswa yang masih bingung. Guru juga menjadikan siswa lain sebagai tutor sebaya dalam mengatasi permasalahan ini.

\section{Lankgah Kerja 5: Pembuktian (Verification)}

Guru menyederhanakan penjelasan dan telah memberikan contoh sebagai model siswa untukenyelesaikan langkah ke-5.

\section{Langkah Kerja 6: Menarik simpulan/ge neralisasi (Generalizati on)}

Guru telah menyiapkan dan memberikan sistematika sederhana disertai conoth secukupnya, sehingga siswa dapat mencontoh dari model yang ada disesuaikan dengan data siswa. Guru juga berhasil memperbaiki cara membimbing khusus siswa yang tidak aktif dengan berbagai teknik memberikan motivasi

Kegiatan penutup: Kegiatan penutup dapat dilaksanakan dengan baik, tidak perlu perbaikan. 


\section{3) Observasi}

Dalam kegiatan ini langkah-langkah tidah jauh berbeda dengan yang dilaksanakan pada siklus I. Untuk prestasi belajar menggunakan tes individual berbasis materi hasil kerja kelompok sebelumnya, guna mengetahui prestasi belajar siswa dari hasil penilaian menggunakan Pembelajaran discovery learning. Observer menggunakan lembar observasi kinerja guru untuk mengamati seluruh pelaksanaan proses pembelajaran.

\section{Prestasi Belajar}

Pada pembelajaran hasil pos tes siklus II diatas menunjukkan bahwa prestasi belajar siswa rata-rata 75,50 . Nilai rata-rata ini telah mengalami peningkatan dibanding sebelum diadakan perbaikan $(+6,00)$. Persentase ketuntasan $87,00 \%$, mengalami peningkatan $(+15,00)$. Persentase ini telah memenuhi indikator kinerja yakni $\geq 85 \%$. Dengan demikian pada siklus II ini telah berhasil mencapai indikator yang ditetapkan yakni rata-rata $\geq 70$ dan persentase ketuntasan $\geq 85 \%$. Dari sisi prestasi belajar siklus II (kedua) telah berhasil.

\section{Kinerja Guru}

Kinerja guru menunjukkan bahwa skor ketuntasan guru dalam menyusun Rencana Pembelajaran APKG I dengan prosestase 95.00. Dibanding siklus I mengalami peningkatan $(+7,00)$. Ketuntasan guru dalam melaksanakan rencana pelaksanaan pembelajaran APKG II 93,00 meningkat $(+11,00)$. Dengan perbaikan proses pembelajaran berhasil memenuhi indikator kinerja yang ditetapkan yakni APKG I $\geq 93,00$ dan APKG II $\geq 91,00$.

\section{4) Refleksi}

Dari keseluruhan analisis data dan pembahasan diatas secara umum pelaksanaan PTK baik dari aspek prestasi belajar siswa maupun kinerja guru telah berhasil mencapai indikator kinerja yang diharapkan.

Keberhasilan ini disebabkan guru dapat memanfaatkan kelibihan-kelebihan model pembelajaran discovery learning sebagaimana dibahas dalam buku pelatihan guru Implementasi Kuriulum 2013, mengatakan mengenai kelebihan dari discovery learning adalah sebagai berikut.

1. Membantu peserta didik untuk memperbaiki dan meningkatkan keterampilanketerampilan dan proses-proses kognitif. Usaha penemuan merupakan kunci dalam proses ini, seseorang tergantung bagaimana cara belajarnya.

2. Pengetahuan yang diperoleh melalui strategi ini sangat pribadi dan ampuh karena menguatkan pengertian, ingatan dan transfer.

3. Menimbulkan rasa senang pada siswa, karena tumbuhnya rasa menyelidiki dan berhasil.

4. Strategi ini memungkinkan siswa berkembang dengan cepat dan sesuai dengan kecepatannya sendiri.

5. Menyebabkan siswa mengarahkan kegiatan belajarnya sendiri dengan melibatkan akalnya dan motivasi sendiri.

6. Strategi ini dapat membantu siswa memperkuat konsep dirinya, karena memperoleh kepercayaan bekerja sama dengan yang lainnya.

7. Berpusat pada siswa dan guru berperan sama-sama aktif mengeluarkan gagasangagasan. Bahkan gurupun dapat bertindak sebagai siswa, dan sebagai peneliti di dalam situasi diskusi. 
8. Membantu peserta didik menghilangkan skeptisme (keragu-raguan) karena mengarah pada kebenaran yang final dan tertentu atau pasti.

9. Siswa akan mengerti konsep dasar dan ide-ide lebih baik.

10. Membantu dan mengembangkan ingatan dan transfer kepada situasi proses belajar yang baru.

11. Mendorong siswa berpikir dan bekerja atas inisiatif sendiri.

12. Mendorong siswa berpikir intuisi dan merumuskan hipotesis sendiri.

13. Memberikan keputusan yang bersifat intrinsik.

14. Situasi proses belajar menjadi lebih terangsang.

15. Proses belajar meliputi sesama aspeknya siswa menuju pada pembentukan manusia seutuhnya.

16. Meningkatkan tingkat penghargaan pada siswa.

17. Kemungkinan siswa belajar dengan memanfaatkan berbagai jenis sumber belajar.

18. Dapat mengembangkan bakat dan kecakapan individu.

Demikian pula peneliti dapat melaksasnakan sintaks discovery learning yang mencakup 6 langkah dengan baik. Dengan terlaksananya pembelajaran penerapan discovery learning, dan tercapainya indikator kinerja yang ditetapkan, maka pelaksanaan penelitian perbaikan pembelajaran siklus II dinyatakan berhasil dan tidak perlu dilanjutkan pada siklus berikutnya.

\section{KESIMPULAN}

Adapun kesimpulan dari hasil penelitian adalah : 1) Penerapan model pembelajaran discovery learning dapat meningkatkan keaktifan dan pprestasi belajar siswa pada pembelajaran Biologi materi metabolisme sel di kelas XII IPA-1 semester I SMAN 1 Palibelo tahun pelajaran 2020/2021; 2) Penerapan model pembelajaran discovery learning dapat meningkatkan kinerja guru Biologi di SMAN 1 Palibelo.

Beberapa saran dan tindak lanjut dari hasil penelitian adalah: 1) Kepada guru untuk menerapkan model pembelajaran discovery learning untuk meningkatkan keaktifan dan pprestasi belajar di kelas XII IPA-1 di SMAN 1 Palibelo; 2) Kepada guru disarankan untuk mengembangakan model pembelajaran discovery learning mata pelajaran lainnya, selain pembelajaran Biologi; dan 3) Kepada sekolah, instansi terkait disarankan untuk dapat menyediakan fasilitas penunjang proses pembelajaran untuk menunjang efektvitas pelaksanaan Kurikulum 2013 baik pada perencanaan, pelaksanaan maupun penilaian pembelajaran, khususnya pada pengembangan model, metode, media pembelajaran dan penilaian pembelajaran secara komprehensif.

\section{DAFTAR PUSTAKA}

A.M., Sardiman. (2001). Interaksi Dan Motivasi Belajar Mengajar. Jakarta: Raja Grafindo Persada.

Alma, Buchari, dkk. (2010). Pembelajaran Studi Sosial. Bandung: CV Alfabeta.

Aqib, Zainal. (2009). Penelitian Tindakan Kelas untuk Guru. Bandung: Yrama Widya.

Arofah, S., Fathoni, A., \& Minarsih, M. M. (2015). Pengaruh Kompensasi, Keahlian danLingkungan Kerja terhadap Kepuasan Kerja Karyawan pada Bank Permata Cabang Bangkong Semarang.Journal of Management, 1(1). 
Ali, Mohammad dan Mohammad Asrori. (2008). Psikologi Remaja Perkembangan Peserta Didik. Jakarta: PT.Bumi Aksara.

B. Suryosubroto. (2009). Proses Belajar Mengajar di Sekolah. Jakarta: PT. RINEKA CIPTA.

Busono, G. A. (2016). Pengaruh Sistem Pelatihan Dan Pengembangan Karyawan Terhadap Kinerja Karyawan Pt. Persada Sawit Mas (PSM) Kecamatan Pampangan Kabupaten Ogan Komering Ilir.Muqtashid, 1(1), 81-114.

Hurlock, Elizabeth B. (2011). Psikologi Perkembangan: Suatu Pendekatan Sepanjang Rentang Kehidupan. Jakarta: Erlangga.

Hadi, S., Tukiran, T., \& Yuwono, B. (2009). Pengaruh Supervisi Akademik, Kompetensi Guru dan Kedisiplinan Terhadap Kinerja Guru SMA Negeri 3 Slawi Kabupaten Tegal.Khazanah Pendidikan, 2(1).

Kemendikbud (2016). Permendikbud Nomor 22 Tahun 2016 Tentang Standar Proses Pendidikan Dan Menengah. Jakarta: Kemendikbud.

Kemdikbud. (2014). Permendikbud No. 103 Tentang Pembelajaran pada Pendidikan Dasar dan Menengah Tahun 2014. Jakarta: Kemdikbud.

Moedjiono dan Dimyati. (1995). Strategi Belajar Mengajar. Jakarta: Depdikbud.

Purwanto, Ngalim. (2006). Psikologi Pendidikan. Bandung: PT Remaja Rosdakarya.

Pratiwi, Noor Komari. (2015). Pengaruh Tingkat Pendidikan, Perhatian Orang Tua, dan Minat Belajar Siswa Terhadap Prestasi Belajar Bahasa Indonesia Siswa SMK Kesehatan Di Kota Tangerang. Jurnal Pujangga Volume 1, Nomor 2, Desember.

Santrock (2003) John W. Adolescence. Perkembangan Remaja. Edisi Keenam. Jakarta: Erlangga. 